\title{
Latitudinal thermal gradient effect on the cost of living of the intertidal porcelain crab Petrolisthes granulosus
}

\author{
Cristián J. Monaco ${ }^{1}$, Katherina B. Brokordt ${ }^{2, *}$, Carlos F. Gaymer ${ }^{1,2}$ \\ ${ }^{1}$ Departamento de Biología Marina, Universidad Católica del Norte, Larrondo 1281, Coquimbo, Chile \\ ${ }^{2}$ Centro de Estudios Avanzados en Zonas Áridas (CEAZA), Universidad Católica del Norte, Larrondo 1281, Coquimbo, Chile
}

\begin{abstract}
Species with wide latitudinal distributions are exposed to significant abiotic gradients throughout their geographic range. Thermal gradients are especially important for ectothermic species inhabiting the intertidal zone because they affect their life history traits and fitness. In order to identify the role of latitudinal thermal gradients (specifically the exposition to different thermal maximums) in the cost of living of intertidal crustaceans, we compared specific fitness-related traits, such as body size and reproductive capacity (reproductive output, size at onset of sexual maturity and egg volume) in Petrolisthes granulosus individuals from 3 sites across an extensive latitudinal gradient (covering $~ 50 \%$ of its total distributional range): Iquique $\left(20^{\circ} 16^{\prime} 12^{\prime \prime} \mathrm{S}\right)$, Coquimbo (30 $\left.04^{\prime} 12^{\prime \prime} \mathrm{S}\right)$ and Concepción $\left(36^{\circ} 40^{\prime} 45^{\prime \prime} \mathrm{S}\right)$. Furthermore, metabolic rate experiments were conducted to assess the energetic cost associated with high temperatures encountered in P. granulosus habitats. We observed that the southernmost population (Concepción) had a larger body size and presented larger size classes that did not exist in northerly populations. The latitudinal trend shown by growth and reproductive capacity traits was negatively linked to the associated thermal gradient. However, no differences were found in the relationship between energetic cost (in terms of metabolic rate) and temperatures experienced by $P$. granulosus. Thus, the patterns of body size and reproductive capacity observed for $P$. granulosus could not be explained by differences in energetic costs generated by the different thermal regimes of the study sites. Further studies should consider other environmental (e.g. quantity and quality of available food) and/or genetic factors that may be influencing the latitudinal patterns observed for body size and reproductive output in P. granulosus.
\end{abstract}

KEY WORDS: Cost of living - Latitudinal thermal gradient $\cdot$ Body size $\cdot$ Reproductive capacity Metabolic rate $\cdot$ Crabs $\cdot$ Petrolisthes granulosus $\cdot$ Rocky intertidal

\section{INTRODUCTION}

Temperature has been described as one of the most important abiotic factors determining distributional patterns of rocky intertidal organisms (Wethey 1983, Stillman \& Somero 1996). Species inhabiting the intertidal zone have developed a series of physiological, morphological and behavioral adaptations that allow them to live in such conditions (e.g. crustaceans, Stillman \& Somero 1996, Stillman 2002; molluscs, Helmuth \& Hofmann 2001; echinoderms, Sanford 2002). Different species have dissimilar physiological ther- mal ranges that enable them to inhabit specific habitats (Stillman \& Somero 1996, Stillman 2002). These ranges are set by both an upper and a lower thermal limit. Considering a latitudinal gradient, species living close to the equator show higher upper thermal limits than those living close to the poles (Stillman \& Somero 2000).

Even though much has been done to identify the physiological, biochemical and molecular adaptations related to thermal stress, there are still many questions regarding the influence of high temperatures on the overall cost of life and the distributional patterns of 
populations (reviewed by Somero 2002). Physiological processes triggered by thermal stress that imply energetic costs include those associated with the synthesis and activity of the stress proteins, elimination and replacement of degraded proteins, restoration of transmembrane gradients and use of anaerobic metabolic pathways (Somero 2002).

In the energy distribution of an ectothermic organism, defined by the energy balance equation (Strong \& Daborn 1979), the physiological cost caused by thermal stress is an important factor that affects the amount of energy that can be allocated to growth and reproduction. Moreover, some authors state that temperature is the main factor regulating growth and reproductive performance in many marine organisms (e.g. Niewiarowski 2001, Angilletta et al. 2004). Evidence of the latter has emerged from both laboratory experiments (e.g. Weetman \& Atkinson 2004) and correlations observed in the field (e.g. Castilho et al. 2007). Weetman \& Atkinson (2004) conducted controlled laboratory experiments with Daphnia spp. and showed that energy became limited at high temperatures. Likewise, Castilho et al. (2007) investigated population structure of the Atlantic shrimp Artemesia longinaris and reported larger body size for populations sampled farther from the tropical regions, which they attributed to low temperatures.

Numerous species from the upper intertidal zone show a small difference between their upper thermal tolerance limits and their maximum environmental temperature (Stillman \& Somero 2000). During frequent and extended periods, these species are exposed to thermal conditions that are close to their physiological thermal limits (Stillman \& Somero 1996). This means that their physiological mechanisms to cope with thermal stress (e.g. synthesis of stress proteins) should be more active, which in turn could imply a high metabolic expenditure in order to survive under such extreme conditions (Stillman \& Somero 2000).

One of the most commonly used physiological parameters to determine metabolic costs is the measurement of metabolic rate (i.e. oxygen consumption). Oxygen consumption for basal metabolism represents the minimum energetic requirements an organism needs for maintenance. In ectothermic species, this metabolic rate is strongly affected by temperature and thus represents a good indicator for the physiological cost associated with a particular thermal condition. Accordingly, we would expect high oxygen consumptions in populations from low latitudes when they are exposed to the maximum temperatures in their environment (Stillman \& Somero 1996).

Certain species show wide latitudinal distributions, and populations exposed to different thermal extremes may experience different physiological costs (Stillman
\& Somero 2000). Porcelain crabs are an ideal study model to evaluate the effects of temperature on the cost of living. They are extremely abundant and many species show wide geographical distributions (Carvacho 1980), which allows comparisons between distant populations.

In the present study, we evaluated the effects of the latitudinal thermal gradient on the cost of living in Petrolisthes granulosus. P. granulosus is a conspicuous mid to high intertidal rocky shore crab that normally copes with high temperatures during each low tide. During these periods it remains under boulders and cobbles to protect itself from heat, desiccation and terrestrial predators. The wide latitudinal range of this species (5 to $36^{\circ} \mathrm{S}$, Haig 1960) allowed us to compare groups of individuals that are separated by hundreds of kilometers and may experience different thermal regimes. We hypothesized that the energetic cost associated with exposure to different thermal maximums would ultimately be reflected in differences in growth and reproductive capacity. Consequently, one should expect to find larger body sizes and higher reproductive output in those individuals exposed to lower temperature regimes, according to their latitudinal distribution. These predictions were tested with field samplings at distant sites and laboratory experiments of the organism's metabolic rates at different water temperatures based on those registered at each site.

\section{MATERIALS AND METHODS}

Study sites, size structure and reproductive capacity. We sampled Petrolisthes granulosus at 3 sites along the Chilean coast: Iquique $\left(20^{\circ} 16^{\prime} \mathrm{S}, 70^{\circ} 07^{\prime} \mathrm{W}\right)$, Coquimbo $\left(30^{\circ} 04^{\prime} \mathrm{S}, 71^{\circ} 22^{\prime} \mathrm{W}\right)$ and Concepción $\left(36^{\circ} 40^{\prime} \mathrm{S}\right.$, $73^{\circ} 05^{\prime} \mathrm{W}$ ) (Fig. 1). This allowed us to cover $\sim 50 \%$ of the distributional range of $P$. granulosus according to Haig (1960) (Fig. 1). A temperature data-logger was installed at each site (StowAway TidBit) to record the environmental temperature every 10 min between 20 December 2006 and 20 February 2007 (Southern Hemisphere summer). The data-loggers were placed under cobbles in the high intertidal zone where $P$. granulosus lives.

In spring (Petrolisthes granulosus reproductive season, Antezana et al. 1965) 2006 we collected 200 $P$. granulosus at each site to determine the size structure at Iquique, Coquimbo and Concepción. At each site, we sampled for $5 \mathrm{~min}$ at six $4 \mathrm{~m}^{2}$ stations separated by $5 \mathrm{~m}$ along a transect that ran parallel to the coastline. We further collected 100 females per site to evaluate their reproductive capacity. Individuals were preserved in sealed bags with $70 \%$ ethanol (Russell 1963) (females were stored individually). 


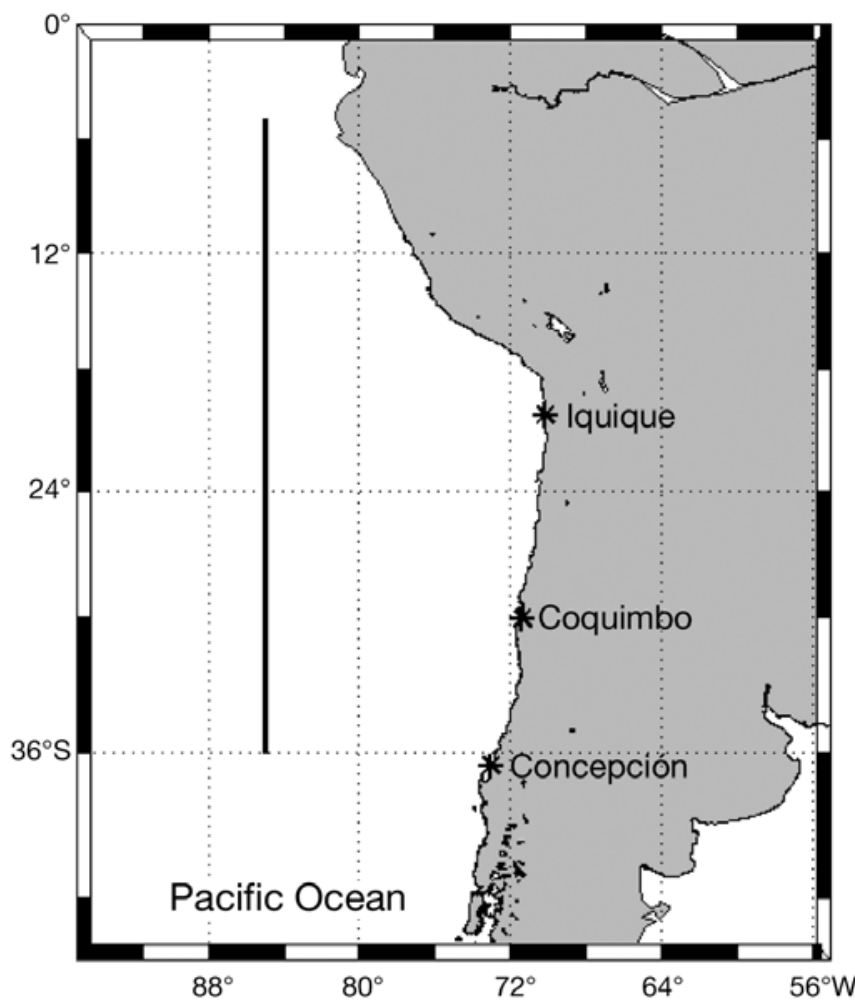

Fig. 1. Latitudinal distribution (solid line) of Petrolisthes granulosus (sensu Haig 1960 and Carvacho 1980). * Study sites: Iquique $\left(20^{\circ} 16^{\prime} \mathrm{S}, 70^{\circ} 07^{\prime} \mathrm{W}\right)$, Coquimbo $\left(30^{\circ} 04^{\prime} \mathrm{S}, 71^{\circ} 22^{\prime} \mathrm{W}\right)$ and Concepción $\left(36^{\circ} 40^{\prime} \mathrm{S}, 73^{\circ} 05^{\prime} \mathrm{W}\right)$

Collected individuals were carried to the laboratory where they were sexed and measured (cephalothorax length and width) to the nearest $0.05 \mathrm{~mm}$. Their wet and dry masses $\left(48 \mathrm{~h}\right.$ at $70^{\circ} \mathrm{C}$ ) were determined using an analytical balance (0.0001 g precision). We extracted the embryos from ovigerous females and determined their dry mass. The observed correlation between female size and embryo dry mass was considered as an indicator of reproductive capacity. For each site, size at onset of sexual maturity was determined by calculating the average cephalothorax length from the 10 smallest ovigerous females (i.e. $10 \%$ ). We further photographed 20 randomly selected eggs per female using a Zeiss AxioStar plus microscope and a Canon PowerShot 620 digital camera. We measured the longest ( $a$ ) and shortest (b) diameter of each egg using image analysis software (AxioVision LE). The egg volume was determined using the equation proposed by Corey \& Reid (1991): egg volume $=1 / 6\left(a b^{2} \pi\right)$. Given that females can lose eggs during embryonic development, we only used females carrying eggs in developmental stage I (E-I), i.e. eggs with uniform yolk and without a visible ocular spot (Lardies \& Wehrtmann 1996).
Metabolic rate measurements. In order to evaluate the energetic cost associated with thermal stress, we quantified standard metabolic rates (i.e. resting and post-absorptive status) of males from Iquique, Coquimbo and Concepción exposed to high temperatures representative of each site. Given that porcelain crabs are water breathers and that we were not looking for desiccation stress responses, we decided to use underwater metabolic rate measurements. Females were not considered here since their response may be influenced by their reproductive status (Brante et al. 2003).

One hundred mid-size (10 to $15 \mathrm{~mm}$ cephalothorax length) individuals per site were collected and transported in coolers with ice-packs to the Facultad de Ciencias del Mar, at Universidad Católica del Norte, Coquimbo. Organisms were acclimated for $7 \mathrm{wk}$ in $45 \mathrm{l}$ aquaria supplied with running unfiltered seawater at $\sim 16^{\circ} \mathrm{C}$. Since Petrolisthes granulosus filter-feeds, crabs could eat throughout the acclimation period.

Standard metabolic rates were measured under 3 thermal categories: (1) the maximum temperature registered at each site during the summer, (2) the average of maximum temperatures recorded every day \pm 30 min (assuming that organisms are exposed for $\sim 1 \mathrm{~h}$ at low tide), and (3) a control temperature, defined by the average temperature experienced by the organisms during the acclimation period in the lab (16 \pm $1^{\circ} \mathrm{C}$ ). The thermal categories were determined according to the temperatures registered at each site during summer 2007 (Table 1, see Fig. 2).

Standard metabolic rates were measured as oxygen consumption of resting males starved for $36 \mathrm{~h}$ and placed in $200 \mathrm{ml}$ glass chambers. In order to reduce manipulation stress, individuals were placed inside their chambers ( 2 crabs per chamber) $12 \mathrm{~h}$ before starting measurements. During that period the chambers were kept open in aquaria with flowing seawater (filtered through a $1 \mu \mathrm{m}$ mesh and oxygenated). Water temperature was raised at a rate of $1^{\circ} \mathrm{C} \mathrm{h}^{-1}$ until the desired treatment temperature was achieved. Oxygen

Table 1. Temperatures $\left({ }^{\circ} \mathrm{C}\right)$ used in the metabolic rate experiments for 3 populations of Petrolisthes granulosus. Two thermal categories (TC) and a control temperature were defined. TC1: maximum temperature registered at each site; TC2: average of maximum temperatures recorded every day \pm 30 min (assuming that organisms are exposed for $\sim 1 \mathrm{~h}$ at low tide); control: defined by the average temperature experienced by the organisms during the acclimation period

\begin{tabular}{|lccc|}
\hline \multirow{2}{*}{$\begin{array}{l}\text { Thermal } \\
\text { category }\end{array}$} & Iquique & Coquimbo & Concepción \\
\cline { 2 - 4 } & 26 & 22 & 19 \\
TC1 & 22 & 20 & 17 \\
TC2 & 16 & 16 & 16 \\
Control & & & \\
\hline
\end{tabular}


consumption of Petrolisthes granulosus was measured in 5 hermetic chambers per treatment (i.e. 5 replicates) for $2 \mathrm{~h}$. For each thermal treatment, we used 2 crabfree chambers as blanks, where we recorded oxygen consumption by microorganisms. The oxygen consumption by the crabs was corrected by each blank. At the end of the experiment, 110 to $120 \mathrm{ml}$ water samples were taken from each chamber and fixed, and their oxygen concentration $\left(\mathrm{ml} \mathrm{O}_{2} \mathrm{l}^{-1}\right)$ was determined using Winkler's method (Carpenter 1965). Given that standard metabolic rates can be affected by body size, all data were standardized by individual dry mass and expressed as $\mathrm{ml} \mathrm{O}_{2} \mathrm{~h}^{-1} \mathrm{~g}^{-1}$.

Statistical analysis. One-way ANOVAs were used to compare mean body size, size at onset of sexual maturity, and average egg volume between sites. Size frequency distributions were contrasted with a $\chi^{2}$ test on contingency tables (Steel \& Torrie 1980). Specific differences between each size range were evaluated through their individual contribution to the global $\chi^{2}$ using an adjusted residual analysis (Agresti 1996). We used a 2-way ANOVA to compare metabolic rates between sites and thermal categories. Normality was evaluated with the Shapiro-Wilk's test and homocedasticity with Levene's test (Steel \& Torrie 1980). Data were $\log _{10}$-transformed when assumptions of normality and homocedasticity were not met. If assumptions were still not met after transformation, ANOVAs were conducted with both raw and ranked data, using the results obtained with the raw data when there were no differences between them (Conover 1980).

Since egg mass is an allometric variable, it was correlated with female body size (e.g. Brante et al. 2004) and compared between populations using analysis of covariance (ANCOVA) (Packard \& Boardman 1999). Applying this analysis removed the effect of the female body size on reproductive capacity, and reduced the risk of wrong conclusions. Previous to ANCOVA we tested homogeneity of regression coefficients (i.e. slopes) using a Fisher test, followed by a Tukey multiple comparisons test (Sokal \& Rohlf 1995). When assumptions of normality and homocedasticity were not met data were transformed as indicated above.

\section{RESULTS}

\section{Environmental temperature}

Environmental temperatures were measured at the exact places where Petrolisthes granulosus was found (i.e. covered areas protected from the direct sun and predators). By doing this we were able to get an idea of the thermal regime the organisms experienced in their habitat and determine the treatment temperatures that were further used for the metabolic experiment. These measurements established the presence of a latitudinal thermal gradient (Fig. 2); the highest temperatures recorded at Iquique, Coquimbo and Concepción were $26.3,21.1$ and $19.1^{\circ} \mathrm{C}$, respectively. The average maximum temperatures recorded every day $\pm 30 \mathrm{~min}$ at Iquique, Coquimbo and Concepción were 22, 20 and $17^{\circ} \mathrm{C}$, respectively. Iquique and Coquimbo had the highest overall temperatures (mean $\pm \mathrm{SE}=18.4 \pm 0.01$ and $18.5 \pm 0.01{ }^{\circ} \mathrm{C}$, respectively), whereas Concepción showed the lowest $\left(15.1 \pm 0.01^{\circ} \mathrm{C}\right)$. On the other hand, thermal variability was greater at Iquique and Concepción and lower at Coquimbo (Fig. 2).
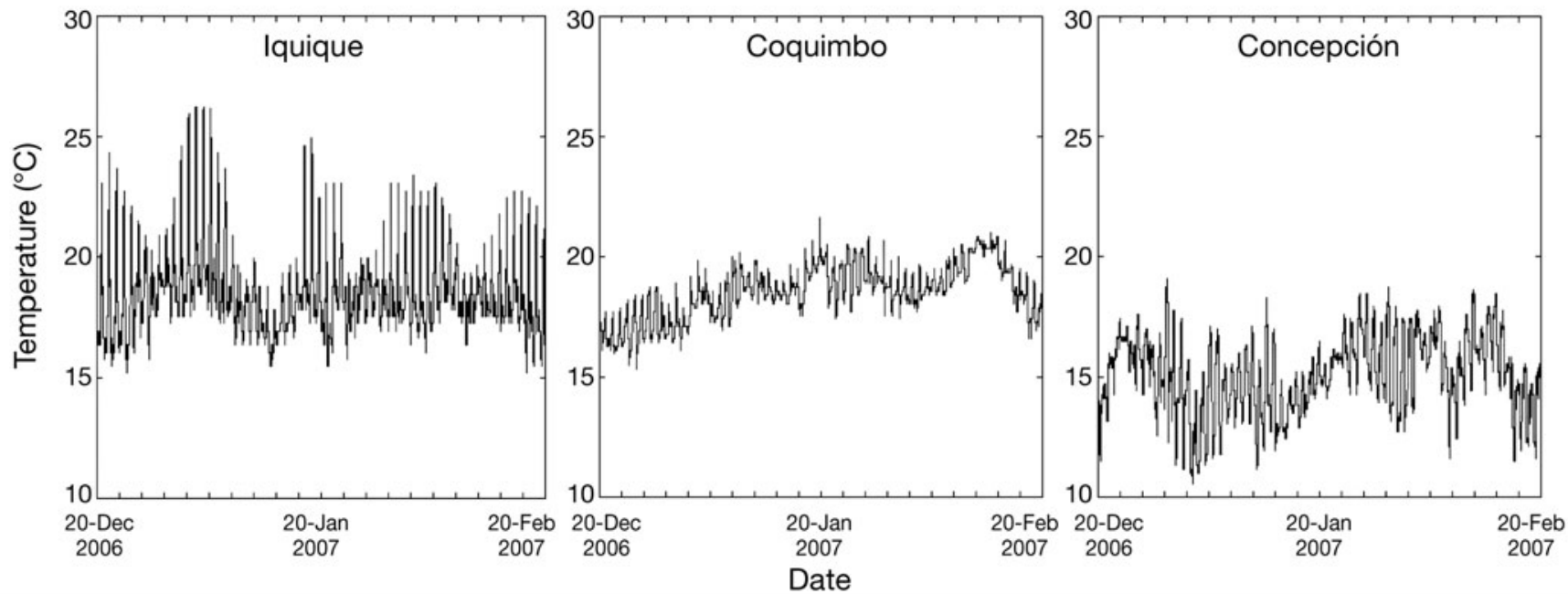

Fig. 2. Environmental temperatures recorded every $10 \mathrm{~min}$ at Iquique, Coquimbo and Concepción between 20 December 2006 and 20 February 2007. Thermal sensors were installed in the high intertidal zone under boulders and cobbles, where Petrolisthes granulosus is normally found 


\section{Body size}

Petrolisthes granulosus body size showed a clear increase with latitude (ANOVA: $F_{2,597}=25.69$, p $<0.01$; Fig. 3), implying an inverse relationship with temperature. The largest size was observed at Concepción, which can be explained by a size distribution skewed to sizes larger than those observed in Iquique and Coquimbo populations (adjusted residual analysis, Fig. 4). Moreover, we found large size classes at Concepción that did not exist at the 2 northern sites.

\section{Reproductive capacity}

Egg masses correlated positively with female size (cephalothorax width) for each sampled site (Fig. 5). Petrolisthes granulosus presented clear differences in reproductive output between the sampled populations (ANOVA, $F_{2,131}=6.92, \mathrm{p}<0.05 ;$ Fig. 5), and females from Concepción had a higher reproductive output than those from Iquique and Coquimbo (Fig. 5). The former was evidenced by a greater rate of increase of egg mass in relation to body size, as shown by a steeper slope (Tukey's test, $\mathrm{p}<0.01$; Fig. 5). Regarding the size at onset of sexual maturity, female $P$. granulosus started to reproduce at smaller sizes towards the north of the species' latitudinal distribution (ANOVA, $F_{2,27}=80.8, \mathrm{p}<0.001$; Fig. 6). No significant differences were observed between Iquique and Coquimbo. On the other hand, egg volume of $P$. granulosus females increased with latitude, being greatest at Concepción, intermediate at Coquimbo and smallest at Iquique $\left(F_{2,142}=107.2, \mathrm{p}<0.001 ;\right.$ Fig. 7$)$.

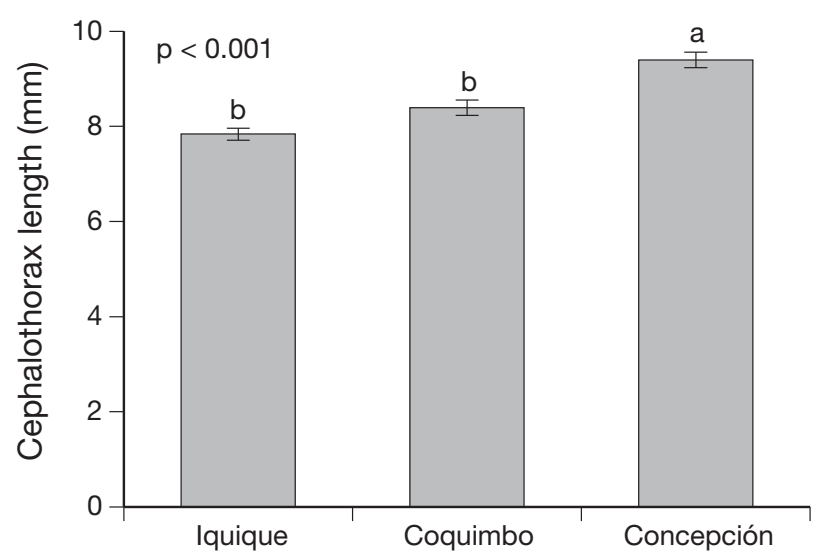

Fig. 3. Petrolisthes granulosus. Average size (cephalothorax length) of $P$. granulosus in the 3 populations (Iquique, Coquimbo and Concepción). A 1-way ANOVA was used to compare means between sites ( $p$-value in figure). Error bars are \pm 1 SE. Populations sharing the same lowercase letter are not significantly different (Tukey's test, $\mathrm{p}>0.05$ )

\section{Standard metabolic rate}

No differences in standard metabolic rates were observed between individuals from Iquique, Coquimbo and Concepción (2-way ANOVA, $F_{2,24}=2.65, \mathrm{p}>$ 0.05; Table 2). Within each population, oxygen consumptions of organisms from Coquimbo and Concep-
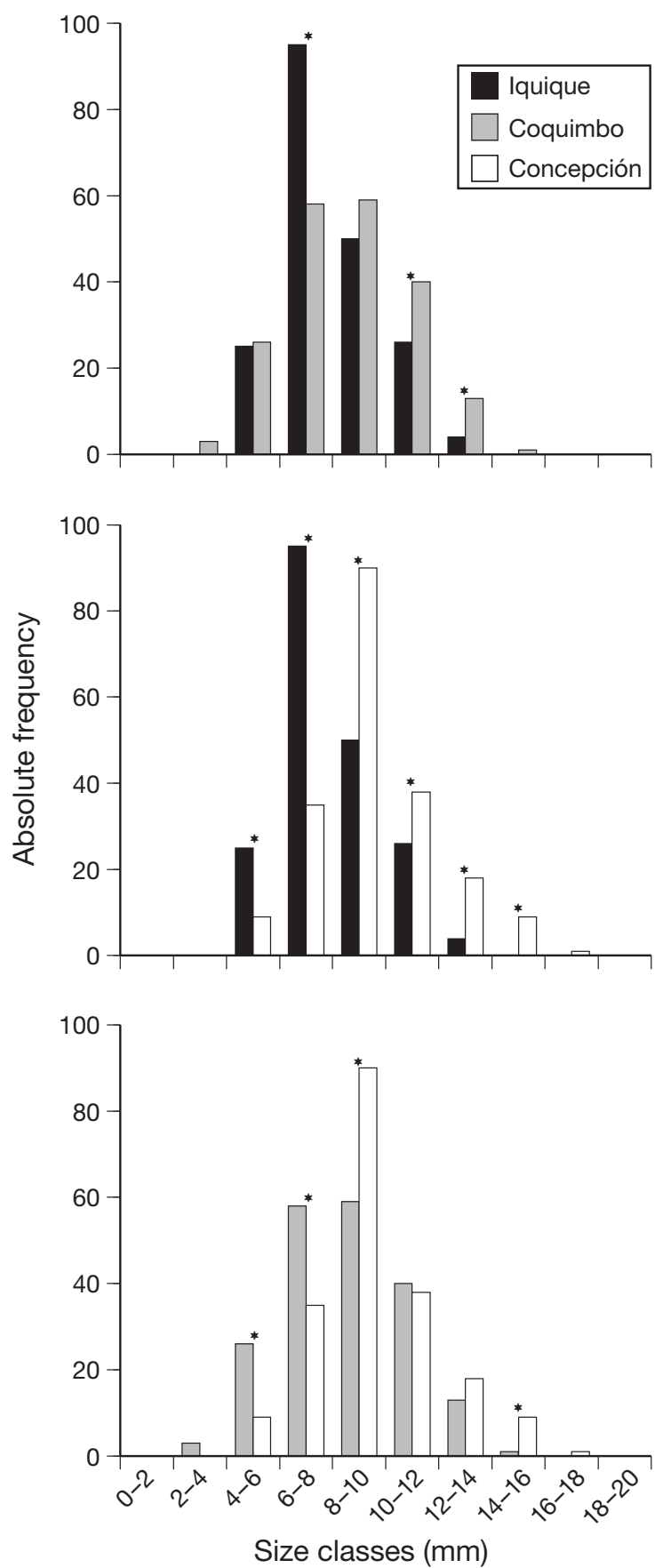

Fig. 4. Petrolisthes granulosus. Size structure of the 3 populations (Iquique, Coquimbo and Concepción). ${ }^{*}$ Significant differences in size between sites for a given size class (adjusted residual analysis) 


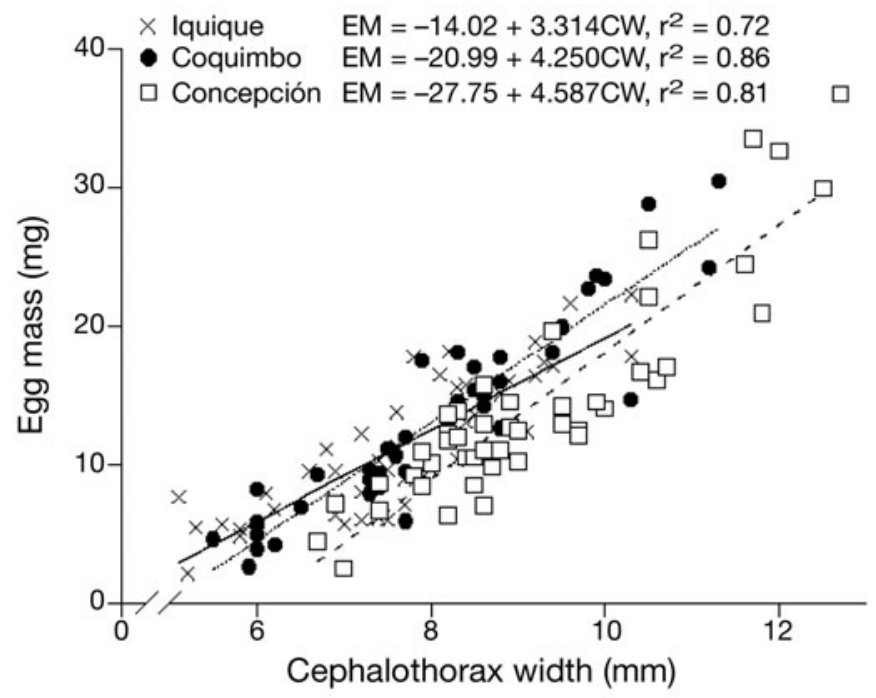

Fig. 5. Petrolisthes granulosus. Correlation between cephalothorax width $(\mathrm{CW}, \mathrm{mm})$ and egg mass (EM, mg) of female crabs from Iquique, Coquimbo and Concepción. Only females carrying stage I eggs were considered

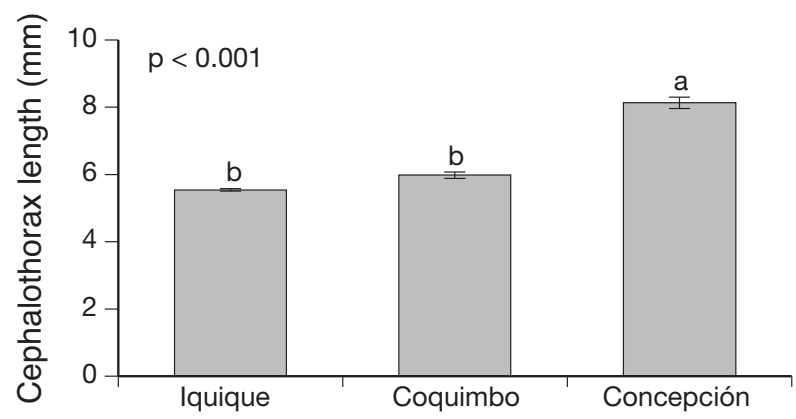

Fig. 6. Petrolisthes granulosus. Size (cephalothorax length) at onset of sexual maturity of 3 populations (Iquique, Coquimbo and Concepción). A 1-way ANOVA was used to compare means between sites ( $p$-value in figure). Error bars are $\pm 1 \mathrm{SE}$. Bars sharing the same lowercase letter are not significantly different (Tukey's test, $\mathrm{p}>0.05$,

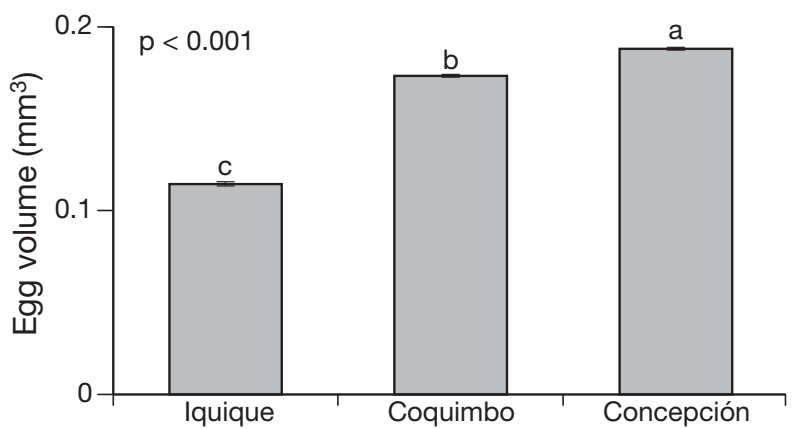

Fig. 7. Petrolisthes granulosus. Average egg volume $\left(\mathrm{mm}^{3}\right)$ from 3 populations (Iquique, Coquimbo and Concepción). A 1-way ANOVA was used to compare means between sites ( $p$-value in figure). Error bars are $\pm 1 \mathrm{SE}$. Bars sharing the same lowercase letter are not significantly different (Tukey's test, $\mathrm{p}>0.05$ )
Table 2. Two-way ANOVA used to compare standard metabolic rates $\left(\mathrm{ml} \mathrm{O}_{2} \mathrm{~h}^{-1} \mathrm{~g}^{-1}\right)$ between male Petrolisthes granulosus from Iquique, Coquimbo and Concepción that were exposed to 3 thermal categories as described in Table 1

\begin{tabular}{|lccc|}
\hline Source & df & $F$ & $p$ \\
\hline Site (S) & 2 & 2.65 & 0.09 \\
Thermal category (TC) & 2 & 6.35 & $<0.001$ \\
S $\times$ TC & 4 & 4.33 & $<0.001$ \\
Error & 24 & & \\
\hline
\end{tabular}

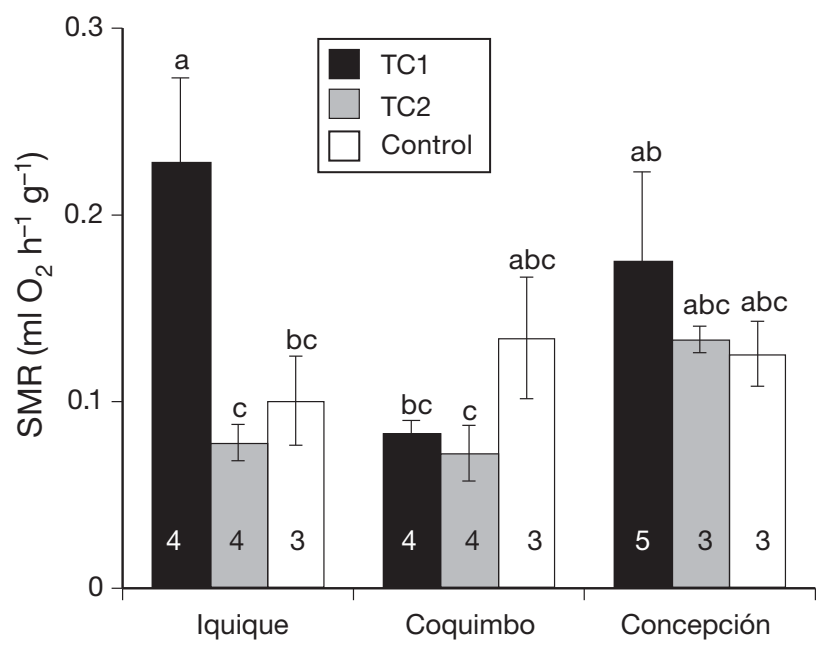

Fig. 8. Petrolisthes granulosus. Standard metabolic rate (SMR) of male crabs from Iquique, Coquimbo and Concepción exposed to 3 thermal categories (TC) (see Table 1 for description and definitions of abbreviations). The exact temperature defined for each thermal category depended on the site (see Table 1). Error bars are $\pm 1 \mathrm{SE}$. Bars sharing the same letter are not significantly different (Tukey's test, $\mathrm{p}>0.05$ ). Numbers on each bar indicate the number of replicates (each replicate included 2 individuals)

ción did not differ significantly from controls when exposed to the maximum temperature and to the average temperature experienced during low tides. In contrast, individuals from Iquique exposed to the maximum recorded temperature $\left(26^{\circ} \mathrm{C}\right)$ showed a higher metabolic rate than those exposed to the average temperature experienced during low tides and to the control temperature $\left(22\right.$ and $16^{\circ} \mathrm{C}$, respectively) (Tukey's test, $\mathrm{p}<0.05$; Fig. 8).

\section{DISCUSSION}

\section{Environmental temperatures}

The high temperatures recorded at each site showed a clear latitudinal gradient, being greatest at Iquique 
and declining towards the south. This confirms the fact that Petrolisthes granulosus from northern populations are exposed to higher temperatures than those from the south. Latitudinal thermal gradients may occasionally be interrupted by site-particular conditions (e.g. increased wave splash, time of low tide), creating microclimates for organisms living there (Helmuth et al. 2006). Even though there was a latitudinal thermal gradient in terms of high and overall temperatures, there was no pattern of thermal variability supported by the organisms from each site; individuals from Iquique and Concepción experienced greater thermal variability than those from Coquimbo. This might have an influence on the way $P$. granulosus are using their energy budget and is something that could be investigated with further experiments.

\section{Body size}

Our results indicated that Petrolisthes granulosus reach larger body sizes towards the south where environmental temperatures are lower. Body size has largely been associated with the well-being of organisms in their habitat (Schmidt-Nielsen 1984, Blackburn \& Gaston 1994). This is because body size can provide an indication of essential processes that may be affecting the performance of organisms (Allen et al. 2006). An increase in body size with latitude is known as Bergmann's rule (Blackburn et al. 1999), a phenomenon that has been observed in a large number of taxa (e.g. crustaceans, Spicer \& Gaston 1999; fish, Wilson 2009; reptiles, Olalla-Tarraga et al. 2006; birds, Olson et al. 2009; mammals, Rodríguez et al. 2008). However, there is still no consensus on the proximal mechanism that may explain this rule. Many factors have been shown to affect body size, but temperature has been proven to be particularly important for ectotherms; a frequently observed developmental phenomenon is that exposure to low temperatures induces cells to grow larger (Van Voorhies 1996, Atkinson \& Sibly 1997). It also has been suggested that high oxygen concentrations found in cold waters induce greater cellular growth; Chapelle \& Peck (1999) used this argument to explain their results obtained from comparing the body size of more than 1500 amphipod species from around the world. The standard metabolic rates measured in the present study show that the environmental temperatures experienced by the crabs from each site do not exert a differential pressure over an individual's energy expenditure. This means that potential differences in cellular growth would not be directly related to energy expenditure shown by the studied organisms. Other factors besides temperature could also explain the differences in cellular growth, such as the length of productivity pulses at different latitudes (Blackburn et al. 1999), differences in growth efficiency between populations (Lindgren \& Laurila 2005) or the age or size at onset of sexual maturity.

\section{Reproductive capacity}

Reproductive output is an index commonly used as a proxy of the relative energy that organisms invest in reproduction (Lardies \& Wehrtmann 1996, Hernáez 2001, Hernáez \& Palma 2003, Lardies et al. 2004). The crabs from Concepción had the highest reproductive capacity among the 3 sites. Moreover, as hypothesized, a negative relationship between reproductive output and environmental temperature was found, since both egg mass and egg volume increased from Iquique towards Concepción. Brante et al. (2004) compared dry egg mass (related to female dry weight) between populations from central and southern Chile using 5 species of brachyuran crabs (Paraxanthus barbiger, Cancer setosus, Homalaspis plana, Ovalipes trimaculatus and Taliepus marginatus). No differences were found along this latitudinal gradient; therefore, Brante et al. (2004) concluded that this variable was poorly affected by temperature gradients or by other environmental factor that could have influenced the energy available for reproduction. However, the species studied were subtidal, and thermal variations associated with the latitudinal gradient are less marked in the subtidal than in the intertidal zone due to the buffering effect of cold seawater that is known to upwell along the Chilean coast. In contrast to these subtidal species, differences in the environmental temperatures found for Petrolisthes granulosus individuals in the present study were greater, which probably explains the higher reproductive output observed at Concepción. Apparently, organisms from Iquique concentrate higher amounts of energy in rapid growth, investing less in reproduction (Lardies \& Castilla 2001). The egg volume in $P$. granulosus increased southwards as well, which confirms previous observations by other studies along a latitudinal gradient in several species of crustaceans (e.g. Wilhelm \& Schindler 2000, Lardies \& Castilla 2001, Brante et al. 2003, 2004). However, Hernáez (2001), who also studied latitudinal variation in egg volume of $P$. granulosus, found no differences between populations. This could be explained by the fact that the latitudinal range he evaluated $(\sim 800 \mathrm{~km})$ was narrower than ours $(1800 \mathrm{~km})$. Lardies \& Castilla (2001), after working with the commensal crab Pinnaxodes chilensis, argued that organisms could lay larger embryos in response to unfavorable environmental conditions that might threaten juvenile survival. Consequently, a larger egg, provided with more energy 
(i.e. yolk), is an adaptation against low temperatures (Thorson 1950, Lardies et al. 2004) and high salinity (Walsh 1993). The fact that P. granulosus dry egg mass also increased southwards confirms the latter; thus southern $P$. granulosus seem to have more energy available to invest in larger egg production.

The length of the incubation period and the number of broods produced per season are life history traits that could also depend on temperature (Dunn 2004, Tieleman 2009) and habitat quality (Nagy \& Holmes 2005). High temperatures may accelerate reproductive processes (Annala et al. 1980), allowing for more than one reproductive event per season. On the other hand, high or stressful temperatures may reduce the energy available for each reproductive event. Accordingly, it would be expected that the total reproductive output for Petrolisthes granulosus populations from low latitudes could be divided into several events, which would imply poor reproductive potential for each individual event. Successive samplings on each of our study sites would be necessary to address this issue.

Our results for Petrolisthes granulosus showed that size at onset of sexual maturity was larger in crabs from Concepción. Other studies on crustaceans have also reported an increase of this parameter with latitude (e.g. Annala et al. 1980, Hernáez 2001). Since temperature stimulates early ovarian development (Annala et al. 1980), the sexual maturation process is accelerated at sites with higher temperatures. On the other hand, Annala et al. (1980) suggested that the size at onset of sexual maturity depends on other factors besides temperature, such as metabolic rates, population density, food availability and other environmental and/or genetic variables. The lack of differences in $P$. granulosus size at onset of sexual maturity between Iquique and Coquimbo, despite the clear differences in environmental temperatures between these 2 sites, suggests that other factors may also be influencing this trait.

The onset of sexual maturity implies that the organism faces a trade-off between the amounts of energy used for reproduction and growth (Stearns 1989, Partridge et al. 1991, Zera \& Harshman 2001). Thus those individuals that start reproducing earlier will have less energy available for growth than those that delay their reproduction. We suggest that this is one of the main factors allowing larger body sizes of Petrolisthes granulosus towards the southern range of distribution.

\section{Standard metabolic rate}

Based on the lack of a site effect, the present study showed that there was no effect of the latitudinal decrease in temperature on Petrolisthes granulosus oxygen consumption. This suggests that temperature is not conditioning one of the main components of the energy budget of this species on a latitudinal gradient. Moreover, within each site, crabs did not increase their metabolic rates (relative to the control) when exposed to the average temperatures experienced during low tides, which implies that the daily temperature rise would not affect $P$. granulosus's energy budget. Individuals from Iquique showed a 3-fold increase in standard metabolic rate when exposed to the maximum temperature recorded, in relation to their response to the average temperature they experience during low tides. Even though $P$. granulosus at Coquimbo and Concepción showed metabolic regulation when faced to temperature changes, the maximum temperature registered at Iquique could exceed the crabs' ability for compensation. High temperatures are deleterious for organisms as they may lead to inactivation and denaturalization of proteins (Heinrich 1977) or limit oxygen supply by restricting their ventilation and circulation capacities (Frederich \& Pörtner 2000). Our results showed that the studied porcelain crabs appear to be adapted to the important temperature fluctuations they experience daily. Since $P$. granulosus inhabits the high intertidal zone, it is reasonable to expect that environmental temperatures would be close to their thermal limit, as also observed for P. cinctipes (Stillman 2002). This means that crabs would be pushed to activate their physiological thermal defense mechanisms and consequently incur an extra energy expense. In light of our results, a temperature increase due to positive thermal anomalies (e.g. El Niño, global warming) would only be harmful for the crabs from the northernmost site. Nevertheless, we did not evaluate the potential response of $P$. granulosus to a prolonged increase in environmental temperature, which might exert a chronic effect.

The fact that the energetic cost (measured as the metabolic rate) associated with temperature did not vary between populations of Petrolisthes granulosus is revealing, since it suggests that these crabs may be adapted to their thermal regime and no associated costs are incurred. Thus it is not possible to state that temperature is responsible for the observed tendencies of growth and reproductive capacity. This is interesting considering that several authors (e.g. Brante et al. 2003, Hernáez \& Palma 2003) have suggested that variations in energy budget between populations could explain some reproductive and body size patterns related to thermal gradients. Even though metabolic rate is considered one of the main components of the energy budget, there are other physiological rates related to the use of energy (e.g. absorption and assimilation efficiencies) that may also be modulated by temperature. Since these physiological traits could also affect growth efficiency and reproductive capacity, it 
would be interesting to evaluate them on $P$. granulosus along a latitudinal gradient. On the other hand, Clarke (1991) stated that species with wide latitudinal distributions could compensate for the loss of metabolic rates due to cold environments by increasing their metabolism in order to maintain their biological functions along their distributional range. This might partially explain the similar metabolic rates shown by P. granulosus along the latitudinal gradient.

It is accepted that oxygen consumption represents a good estimation of the control that metabolic rate has over different ecological processes (Brown et al. 2004); however, it may not be sensitive enough to detect finer scale processes (e.g. energetic expenses associated with the synthesis of heat shock proteins and antioxidative enzymes). In the future, we hope to measure activities of aerobic and anaerobic enzymes that regulate metabolic pathways, or to directly measure stress proteins (e.g. Hsp70) that might be generated after an exposure to different temperatures (e.g. Brokordt et al. 2009).

The similar metabolic rates between crabs from different sites invites us to consider other environmental factors besides temperature that might be partially responsible for the observed trends in Petrolisthes granulosus life history. Physiological cost imposed by wave action is one of the elements to be considered. After working with the mussel Mytilus edulis, Carrington (2002) suggested that motion force of water could affect energy budget and limit reproductive output. Also, ecological interactions (e.g. competition and predation) (Connell 1961, Paine 1974, Sanford 2002) have been suggested to influence an organism's energy balance. Between-site differences in food availability could also affect the energy budget. In order to approach this matter, and considering the filter feeding nature of $P$. granulosus, we compared mean chlorophyll a concentration registered during the period (12 mo) previous to crab sampling (Antares network, www.antares.ws). The concentrations estimated (mean $\pm \mathrm{SE}$ ) for Iquique, Coquimbo and Concepción were $6.4 \pm 1.8,4.8 \pm 1.2$, and $6.4 \pm 2.7 \mathrm{mg} \mathrm{m}^{-3}$, respectively. Since no significant differences were detected between sites (ANOVA, p > 0.05), food availability does not seem to be determining the observed life history trends. However, we are aware that this is not certain proof that the crabs from the 3 sites are eating the same food in terms of amount and quality. Despite the food availability, there are other factors such as the levels of sediment in the water (Donahue 2004) which may reduce the effective food they are able to filter. As a corollary, it still remains to be evaluated to what extent life history traits, body size and reproductive output are determined by other environmental and/or genetic factors.
In summary, our work showed that Petrolisthes granulosus has larger body sizes and higher reproductive capacity towards the southern end of its distributional range. Unexpectedly, metabolic rates measured under representative environmental temperatures from each site did not vary along the latitudinal gradient considered in the present study. Future investigation should consider other factors besides temperature (i.e. environmental and/or genetic factors) that might be determining the observed reproductive and body size patterns.

Acknowledgements. We are grateful to K. Jeno, G. Gamboa, A. Vallejos and G. Nuñez for their help in field sampling. M. Thiel and A. T. Palma made useful suggestions for improving the paper. The study was supported by 2 Fondo Nacional de Desarrollo Científico y Tecnológico, Chile (FONDECYT, Chile) grants (nos. 1050291 and 3030007) to K.B.B. and C.F.G., respectively.

\section{LITERATURE CITED}

Agresti A (1996) An introduction to categorical data analysis. John Wiley \& Sons, New York

Allen CR, Garmestani AS, Havlicek TD, Marquet PA and others (2006) Patterns in body mass distributions: sifting among alternative hypotheses. Ecol Lett 9:630-643

Angilletta MJ, Steury TD, Sears MW (2004) Temperature, growth rate, and body size in ectotherms: fitting pieces of a life-history puzzle. Integr Comp Biol 44:498-509

Annala JH, McKoy JL, Booth JD, Pike RB (1980) Size at onset of sexual maturity in female Jasus edwardsii (Decapoda: Palinuridae) in New Zealand. NZ J Mar Freshw Res 14: $217-227$

Antezana T, Fagetti E, López MT (1965) Observaciones bioecológicas en decápodos comunes de Valparaíso. Rev Biol Mar 12:1-60

Atkinson D, Sibly RM (1997) Why are organisms usually bigger in colder environments? Making sense of a life history puzzle. Trends Ecol Evol 12:235-239

Blackburn TM, Gaston KJ (1994) Animal body-size distributions: patterns, mechanisms and implications. Trends Ecol Evol 9:471-474

> Blackburn TM, Gaston KJ, Loder N (1999) Geographic gradients in body size: a clarification of Bergmann's rule. Divers Distrib 5:165-174

Brante A, Fernández M, Eckerle L, Mark F, Pörtner HO, Arntz W (2003) Reproductive investment in the crab Cancer setosus along a latitudinal cline: egg production, embryo losses and embryo ventilation. Mar Ecol Prog Ser 251: 221-232

Brante A, Cifuentes S, Pörtner HO, Arntz W, Fernández M (2004) Latitudinal comparisons of reproductive traits in five brachyuran species along the Chilean coast. Rev Chil Hist Nat 77:15-27

Brokordt K, Leiva N, Jeno K, Martínez G, Winkler F (2009) Effect of allozyme heterozygosity on basal and induced levels of heat shock protein (Hsp70), in juvenile Concholepas concholepas (Mollusca). J Exp Mar Biol Ecol 370: $18-26$

Brown JH, Gillooly JF, Allen AP, Savage VM, West GB (2004) Toward a metabolic theory of ecology. Ecology 85: 1771-1789 
Carpenter J (1965) The Chesapeake Bay Institute technique for the Winkler dissolved oxygen method. Limnol Oceanogr 10: 141-143

Carrington E (2002) The ecomechanics of mussel attachment: from molecules to ecosystems. Integr Comp Biol 42: 846-852

Carvacho A (1980) Los porcelánidos del Pacífico Americano: un análisis biogeográfico (Crustacea: Decapoda). An Cent Cienc Mar Limnol 7:249-258

Castilho AL, Gavio MA, Costa RC, Boschi EE, Bauer RT, Fransozo A (2007) Latitudinal variation in population structure and reproductive pattern of the endemic South American shrimp Artemesia longinaris (Decapoda: Penaeoidea). J Crustac Biol 27:548-552

> Chapelle G, Peck LS (1999) Polar gigantism dictated by oxygen availability. Nature 399:114-115

Clarke A (1991) What is cold adaptation and how should we measure it? Am Zool 31:81-92

> Connell JH (1961) The influence of interspecific competition and other factors on the distribution of the barnacle Chthamalus stellatus. Ecology 42:710-723

Conover WJ (1980) Practical nonparametric statistics. John Wiley \& Sons, New York

Corey S, Reid DM (1991) Comparative fecundity of decapod crustaceans. I. The fecundity of thirty-three species of nine families of caridean shrimp. Crustac Int J Crustac Res 60: 270-294

> Donahue MJ (2004) Size-dependent competition in a gregarious porcelain crab Petrolisthes cinctipes (Anomura: Porcellanidae). Mar Ecol Prog Ser 267:219-231

Dunn P (2004) Breeding dates and reproductive performance. Adv Ecol Res 35:69-87

Frederich M, Pörtner HO (2000) Oxygen limitation of thermal tolerance defined by cardiac and ventilatory performance in spider crab, Maja squinado. Am J Physiol Regul Integr Comp Physiol 279:R1531-R1538

Haig J (1960) The Porcellanidae (Crustacea, Anomura) of the eastern Pacific. Allan Hancock Pac Exped 24:1-440

Heinrich B (1977) Why have some animals evolved to regulate a high body temperature? Am Nat 111:623-640

- Helmuth BS, Hofmann GE (2001) Microhabitats, thermal heterogeneity, and patterns of physiological stress in the rocky intertidal zone. Biol Bull 201:374-383

Helmuth B, Broitman BR, Blanchette C, Gilman S and others (2006) Mosaic patterns of thermal stress in the rocky intertidal zone: implications for climate change. Ecol Monogr 76:461-479

Hernáez P (2001) Producción y rendimiento reproductivo en Petrolisthes granulosus (Decapoda, Anomura, Porcellanidae) en diferentes localidades del norte de Chile: una comparación latitudinal. Invest Mar 29:73-81 (with English Abstract)

Hernáez P, Palma S (2003) Fecundidad, volumen del huevo y rendimiento reproductivo de cinco especies de porcelánidos intermareales del norte de Chile (Decapoda, Porcellanidae). Invest Mar 31:35-46 (with English Abstract)

- Lardies MA, Castilla JC (2001) Latitudinal variation in the reproductive biology of the commensal crab Pinnaxodes chilensis (Decapoda: Pinnotheridae) along the Chilean coast. Mar Biol 139:1125-1133

Lardies MA, Wehrtmann IS (1996) Aspects of reproductive biology of Petrolisthes laevigatus (Guérin, 1835) (Decapoda, Anomura, Porcellanidae). I. Reproductive output and chemical composition of eggs during embryonic development. Arch Fish Mar Res 43:121-135

Lardies MA, Rojas JM, Wehrtmann IS (2004) Breeding biology and population structure of the intertidal crab Petro- listhes laevigathus (Anomura: Porcellanidae) in centralsouthern Chile. J Nat Hist 38:375-388

Lindgren B, Laurila A (2005) Proximate causes of adaptive growth rates: growth efficiency variation among latitudinal populations of Rana temporaria. J Evol Biol 18:820-828

> Nagy LR, Holmes RT (2005) To double-brood or not? Individual variation in the reproductive effort in black-throated blue warblers (Dendroica caerulescens). Auk 122:902-914

> Niewiarowski PH (2001) Energy budgets, growth rates, and thermal constraints: toward an integrative approach to the study of life-history variation. Am Nat 157:421-433

Olalla-Tárraga MA, Rodríguez MA, Hawkins BA (2006) Broad-scale patterns of body size in squamate reptiles of Europe and North America. J Biogeogr 33:781-793

- Olson VA, Davies RG, Orme CDL, Thomas GH and others (2009) Global biogeography and ecology of body size in birds. Ecol Lett 12:249-259

> Packard GC, Boardman TJ (1999) The use of percentages and size-specific indices to normalize physiological data for variation in body size: Wasted time, wasted effort? Comp Biochem Physiol A 122:37-44

Paine RT (1974) Intertidal community structure: experimental studies on the relationship between a dominant competitor and its principal predator. Oecologia 15:93-120

> Partridge L, Sibly R, Beverton RJH, Hill WG (1991) Constraints in the evolution of life histories (and discussion). Philos Trans R Soc Lond B Biol Sci 332:3-13

Rodríguez MA, Olalla-Tárraga MA, Hawkins BA (2008) Bergmann's rule and the geography of mammal body size in the Western Hemisphere. Glob Ecol Biogeogr 17:274-283

Russell HD (1963) Notes on methods for the narcotization, killing, fixation, and preservation of marine organisms. Marine Biological Laboratory, Systematics-Ecology Program, Woods Hole, MA

Sanford E (2002) Water temperature, predation, and neglected role of physiological rate effects in rocky intertidal communities. Integr Comp Biol 42:881-891

Schmidt-Nielsen K (1984) Scaling: Why is animal size so important? Cambridge University Press, New York

Sokal RR, Rohlf FJ (1995) Biometry: the principles and practice of statistics in biological research. W. H. Freeman, New York

> Somero GN (2002) Thermal physiology and vertical zonation of intertidal animals: optima, limits, and cost of living. Integr Comp Biol 42:780-789

Spicer JI, Gaston KJ (1999) Amphipod gigantism dictated by oxygen availability? Ecol Lett 2:397-403

Stearns SC (1989) Trade-offs in life-history evolution. Funct Ecol 3:259-268

Steel R, Torrie J (1980) Principles and procedures of statistics, a biometrial approach. McGraw Hill, New York

> Stillman JH (2002) Causes and consequences of thermal tolerance limits in rocky intertidal porcelain crabs, genus Petrolisthes. Integr Comp Biol 42:790-796

Stillman JH, Somero GN (1996) Adaptation to temperature stress and aerial exposure in congeneric species of intertidal porcelain crabs (genus Petrolisthes): correlation of physiology, biochemistry and morphology with vertical distribution. J Exp Biol 199:1845-1855

Stillman JH, Somero GN (2000) A comparative analysis of the upper thermal tolerance limits of eastern Pacific porcelain crabs, genus Petrolisthes: influences of latitude, vertical zonation, acclimation and phylogeny. Physiol Biochem Zool 73:200-208

Strong KW, Daborn GR (1979) Growth and energy utilization of the intertidal isopod Idotea baltica (Pallas) (Crustacea: Isopoda). J Exp Mar Biol Ecol 41:101-123 
Thorson G (1950) Reproductive and larval ecology of marine bottom invertebrates. Biol Rev Camb Philos Soc 25:1-45

Tieleman BI (2009) High and low, fast and slow: complementary contributions of altitude and latitude to understand life-history variation. J Anim Ecol 78:293-295

> Van Voorhies WA (1996) Bergmann size clines: a simple explanation for their occurrence in ectotherms. Evolution 50:1259-1264

> Walsh CJ (1993) Larval development of Paratya australiensis Kemp, 1917 (Decapoda, Caridea, Atyidae), reared in the laboratory, with comparisons of fecundity and egg and larval size between estuarine and riverine environments. J Crustac Biol 13:456-480

Editorial responsibility: Marc Weissburg,

Atlanta, Georgia, USA
Weetman D, Atkinson D (2004) Evaluation of alternative hypotheses to explain temperature-induced life history shifts in Daphnia. J Plant Res 26:107-116

Wethey DS (1983) Geographic limits and local zonation: the barnacles Semibalanus (Balanus) and Chthamalus in New England. Biol Bull 165:330-341

Wilhelm FM, Schindler DW (2000) Reproductive strategies of Gammarus lacustris (Crustacea: Amphipoda) along an elevation gradient. Funct Ecol 14:413-422

Wilson AB (2009) Fecundity selection predicts Bergmann's rule in syngnathid fishes. Mol Ecol 18:1263-1272

Zera AJ, Harshman LG (2001) The physiology of life history trade-offs in animals. Annu Rev Ecol Syst 32:95-126

Submitted: May 15, 2009; Accepted: January 8, 2010

Proofs received from author(s): March 10, 2010 